\title{
Seeing Speech as Spectacle in The White Devil
}

\begin{abstract}
:
This article argues that, in the early seventeenth-century, rhetorical devices and stage devices overlap. There has been much critical interest in the materiality of theatres like the Blackfriars, the Globe, and the Red Bull. Recent work in early modern theatre studies has made some broad gestures to the way in which poetic and verbal effects are linked with the practical theatrical work of the playhouse. Rhetoric and rhetorical style have also been subject to renewed scholarly interest, with some suggesting the imminence of an "aesthetic turn" or "New Formalism." Yet, these two critical approaches often remain distinct. Attention to the interaction between speech and spectacle can unite ostensibly different angles of literary analysis and deliver further attention to the visual, philosophical, and intellectual complexity of seventeenth-century playhouse spectacle.

I begin by exploring some important terms in early modern English that point to rhetoric's participation in the material world and that suggest these two approaches, when considered from an historical perspective, are complementary. I then attend to the dumb shows and to light and darkness in John Webster's The White Devil (1612) to argue for a critical approach to early modern theatre studies that combines historically-minded close reading with recent revisionist considerations of spectacle and that sees rhetorical style as part of the visual and material world of the playhouse.
\end{abstract}

\section{Article:}

See, here he comes

---Francisco, The White Devil (1.2.45)

There has been much recent critical interest in the materiality of theatres like the Blackfriars, the Globe, and the Red Bull (Gurr and Karim-Cooper; Griffith; Karim-Cooper and Stern; Harris; Harris and Korda; Sofer). At the same time, from a different approach, early modern rhetoric and rhetorical style — the art of using language effectively to particular ends- 
have been subject to renewed scholarly focus (Mack; McDonald; Skinner). This interest in formal close reading is tangentially connected to a move in the last decade, suggested by Richard Meek, towards an "aesthetic turn" or "New Formalism" (7; see also Christopher Pye and Mark Robson). Marrying these two recent approaches can illuminate complex moments of stage display - particularly in the uncertain, spectacular playworlds of early seventeenthcentury tragedies and tragicomedies and in Shakespeare's "late/last plays." In this article, I explore some important terms in early modern English that point to rhetoric's participation in the material world and that suggest these two approaches, when considered from an historical perspective, are complementary. I go on to address aspects of John Webster's The White Devil (1612) where speech and spectacle are intertwined.

Early modern theatre studies has made some important gestures towards the way in which poetic and verbal effects are linked with the practical theatrical work of the playhouse. Gwilym Jones's recent study of storms has shown that staged effects affect Shakespeare's language, arguing that "Shakespeare seriously considered the impact of the special effects of thunder and lightning when writing staged storms" (153). Shakespeare's Theatres and the Effects of Performance (2013), edited by Farah Karim-Cooper and Tiffany Stern, presents the work of theatre historians and literary critics who view "theatrical effects as an extension of textuality" and insists that there is "no binary between the materiality of theatre and the emotional, metaphorical and poetic registers of the plays themselves" (Karim-Cooper and Stern 3). Indeed, spectacle has been under scrutiny from critics displaying a renewed interest in theatrical self-awareness, from Joanne Rochester's attention to the self-consciousness of spectacle to Chloe Porter's examination of "dramatists' engagements with processes of visual construction as metatheatrical moments of reflection on the significance of representational activity" (1). These studies recognize that spectacle is embedded in a complex array of intellectual, philosophical, and material interactions. From the angle of close reading of verbal style, Russ McDonald's analysis of late Shakespearean verse demonstrates that a recognition of correspondences "between minute grammatical particulars and broad organizational principles helps to show how style makes meaning" (40), and Katherine Acheson has shown that visual representation in early modern England has its own rhetorical structures that range from geometry to classical oratory. Advancing the two-way points of 
connection between formal verse features and the physical facts of the playhouse can further understanding of the way verbal and visual styles work together. Indeed, beyond connecting metaphoric or poetic language to theatrical effects, there is a direct and reciprocal relationship between staged spectacle and the features and effects of early modern rhetoric.

The self-conscious merging of verbal and visual style is acute in plays of the early Jacobean period, when elaborate stage devices are being developed in court performances and staged spectacle fashioned for "intimate" indoor playhouses (see Penelope Woods's on "intimacy" and Paul Menzer on actor-audience proximity). In this period, Webster, Shakespeare, Middleton, and Marston, amongst others, employ distinctly archaic visual forms that are necessarily accompanied by contrived verbal description, particularly the tableau and dumb show; these forms are clear, for instance, in Webster, but are also present in moments that have the quality or essence of dumb shows, as in Jupiter's descent in Cymbeline (see Marion Lomax 31). At the same time, the Jacobean period sees the development of versenotably in Shakespeare and Webster-that responds to Elizabethan rhetorical ornamentation Comment [CD1]: Edited as requested (but escaped tracked changes) by exaggerating and drawing attention to its constructedness, contorting syntax, and shifting between registers and modes.

Such rhetorical style is intimately bound up with the physical materials of theatrical representation. The overlapping meanings of the terms "matter," "engine," and "device"discussed below—show that the visual and verbal realms of the early modern playhouse are closely connected. Webster's The White Devil is a text in which such terms are charged with particular representational significance; understanding the various "devices" and "matters" of the play suggests a relationship between speech and spectacle in the Jacobean playhouse that can unite ostensibly separate critical interests.

\section{Four terms.}

The White Devil, with its idiosyncratic verbal style, represents an acute merging of rhetorical features with visual display, surrounding a variety of dramatic "inventions"particularly in lighting and in the dumb shows. "Invention" is a term that features formally in classical rhetorical theory as well as in the technological innovations of the early modern period. Thomas Wilson, author of the period's first and most popular English manual of 
rhetoric, explains that the first stage of rhetoric is the "finding out of apte matter"-also known as "invention." This stage denotes the "searchyng out of thynges true, or thynges likely, the whiche maie reasonably sette furth a matter, and make it appere probable" (A3v). "Invention" is also used, however, to describe technological developments and physical creations, with titles along the lines of William Bourne's Inuentions or deuises (1590) and, later in the seventeenth century, John Evelyn's library collection devoting a category to "inventions Mechanic, Trades, Work, Vasal \&c." (Evelyn Papers).

As such, "invention" is related to three similar words: "device," "engine," and "matter." All three terms signify verbal "invention" as well as physical or technological inventions.

"Matter" features in Wilson's description of the classical rhetorical stage of "invention":
i. Inuencion of matter.
ii. Dispocisicion of the same.
iii. Elocucion.
iv. Memorie.
v. Utteraunce. (A3v)

Gathering pertinent "material" on a subject forms the building blocks—-the matter—of rhetorical construction. Matter here echoes its Aristotelian origins and its contemporary mechanical connotations in representing the "stuff" of verbal construction. Indeed, the term has resonances beyond rhetoric, appearing variously in anatomical texts to represent physical substance (i.e. "elementary matter" in Crooke's 1615 Mikrokosmographia, B3v) and in inventions and machines (Cornelius Drebbel's perpetual motion machine makes use of "mineral matter," Tymme I3v). In its broadest and most abstract terms, "matter" signifies "an event, circumstance, fact, question, state or course of things" (OED, 1.a)-something that can broadly be extended to remarks, current throughout all early modern English discourses, along the lines of "what's the matter?" (The White Devil 1.2.57). ${ }^{1}$ It is ultimately a term prominently associated with both classical rhetoric and with mechanical "inventions"- two crucial features of the Jacobean stage. 
Material and verbal meanings similarly inhere in the polyvalent terms "device" and "engine." "Deuise" is a remarkably polysemous word in early modern England. The Oxford English Dictionary attests to the contradictory definitions current in the period: among its many meanings, it is both "something devised or framed by art or inventive power; an invention, contrivance; esp. a mechanical contrivance (usually of a simple character for some particular purpose)" and, simultaneously, "used of things non-material" (OED "device, n.," 7a. and b.). Henri Estienne's emblem theory, translated into English in 1646 by Thomas Blount, indicates the "true Etimologie of the word": it is "by it . . . that we represent and discover humane passions, hopes, feares, doubts, disdaine, anger, pleasure . . . and all other motions of the soule" $(\mathrm{C} 1 \mathrm{v})$. In the context of emblems, impresa, exempla, and sententiae, the verbal connotations of "deuise" are drawn to the fore. Emblem theory sees such "devices" as deeply rhetorical, and Claude Mignault's preface to Emblamata (1616) aligns them with the rhetorical arts:

Sed \& oratio variis verborum rerúmque pigmentis \& lenociniis Rhetoricae artis elaborata Emblematis referta dici figuratè potest.

[But also, discourse that is elaborated with various colourings of words and matter, and with the allurements of the Art of Rhetoric, can figuratively be said to be crammed with Emblems] (A8r).

Yet Bourne's Inventions or Devises (1590) uses the term to refer to matters of engineering, and his list of various devices includes winches and cranes and stretches from martial affairs at sea to the construction of in-land fortifications. Henry S. Turner explains that "Evidence from the Revels Office indicates that within a practical milieu the term 'device' could designate simultaneously an idea, invention or conceit; the actual show or entertainment itself; and finally the sketch, 'outline', or plat that was used in the process of realizing the conceit in its material, mechanical form" (129). As such, the term connotes a number of (potentially conflicting) states or concepts, including the idea of a thing and the thing itself-and, importantly, both elaborate verbal and physical construction. "Devise" is therefore closely aligned with the early modern emblem tradition, which likewise offers visual images and 
verbal mottos that are enigmatically or, at times, indifferently connected (see Michael Bath, $74,119)$

"Engine" is likewise used to describe mental, intellectual, or ingenious plans and designs as well as being a term for "engineered" objects from weapons to masque-scenery; it also features repeatedly in Bourne's text, as well as, for instance, dismissively in relation to the "body" of a court spectacle in Jonson's "Expostulation to Inigo Jones" (1633). Thomas Combe's translation into English of Guillaume La Perrière's Le Théâtre des bons engins in the early 1590 s brings engine and device into close connection, and he translates the title of this emblem collection as The Theatre of Fine Devices $(1593,1614)$. The semantic similarity assumed by Combe of the French engin and the English "device" suggests an equivalence between visual and verbal media contained within all four terms: invention, matter, device, engine.

The matter of The White Devil.

The implied theatricality of La Perrière's collection is telling, and action in The White Devil frequently hinges upon the conceptual doubleness of these four terms. Webster explicitly employs the words "matter" and "engine" in moments of heightened (above the already pervasive) visual and ethical confusion. My reading of The White Devil is indebted to Subha Mukherji's study of image-making, in which she notes that "the play is preoccupied with various orders of images, with inventions and creatures of the imagination; with the drawing of pictures-insinuative, suggestive, iconic, legal and memorial" (146). Alongside the play's presentation and interpretation of images, the interaction between stage construction and rhetorical construction offers a means of appreciating the sophistication of seventeenthcentury spectacle.

Physical dramaturgy is linked to the complexity of the play's rhetorical style, which is filled with "engines," "circumstances," and "matter" of its own. Indeed, Webster's verse has been characterized as particularly conspicuous. Critics have noted the "sharp modulations of language" that characterise his writing, in which the "frontier between prose and verse is rapidly crossed and recrossed" (Berry 27). The "frequency, variety, and abruptness" of his "transitions" from one mode to another, from verse to prose, and from full line lengths to 
stunted expression (Berry 29) contribute to a particularly idiosyncratic style (see also Coleman and Pearson). The play's verbal and visual self-awareness can also be detected in the references to "matter":

FRA. Sir, what's the matter?

BRA. I will not chase more blood from that loved cheek,

you have lost too much already; fare you well

FRA. How strange these words sound? [ . . ] (3.2.298-300)

Francisco draws in the many meanings of matter, noting that an emotional matter is at stake but also sparking awareness that Bracciano's lines are themselves "strange" in their sound: they move from an iambic verse line to a hypermetric one. It could be read as a transition from verse to prose, or simply an upset in metrical regularity. The advertising of such "strange" stylized speech makes Webster's play a useful starting place through which to approach the connected "matters" of the theatre, and certainly a host of "strange tongue[s]" (3.2.18) ring throughout the playworld.

The chief answer to Francisco's question-what's the matter?-is that Isabella is dead. Rhetorical style and composition are at the heart of the visual and moral complexity of Camillo's and Isabella's deaths, which are both presented in dumb shows. The stage action here takes place in a dreamlike space, one only accessible to Bracciano-and through him to the audience—thanks to a "magic" nightcap: "Put on this night-cap, sir, 'tis charmed?" (2.2.21). The dreamlike aspects of the dumb shows undermine the certainty of the action: they are crucially not an unmediated presentation of the murders but a "charmed" representation (for a discussion of these "layers" of media, see Katherine M. Carey). Characters on stage therefore remain confused as to the veracity and nature of events that unfold in a dimension removed from the "present."

That confusion prompts the Conjuror and Bracciano to describe the spectacular murders at this moment as "circumstances":

I'll show you you by my strong-commanding art 
The circumstance that breaks your Duchess' heart. (2.2.22-23)

'Twas quaintly done, but yet each circumstance

I taste not fully. (2.2.38-39)

"Circumstance" is a rhetorical term often used in legal matters, where it does not connote straightforward "truth" but rather acts as a means of persuading an auditor. Wilson's Arte notes that an orator would use "circumstance" to set out "any matter, and to amplify it in the uttermost" (C2r). ${ }^{2}$ Circumstances are the what, where, why, whom, how of a narrative event. Bracciano and the Conjuror conceive of the stage action in rhetorical terms, drawing attention to the construction and presentation of evidence. Mukherji recognizes that "the conjurations too are 'inventions,"' like Vittoria's earlier dream, which is itself a "rhetorical artefact" (144, 139). Webster posits the dumb shows as visual equivalents of persuasive speech: they become both rhetorical and theatrical devices.

Reading speech and spectacle together supports Jenny Sager's recent claim "that sensory delight and intellectual contemplation are not mutually exclusive, they are inextricably linked: spectacle provokes 'wonder', which in turn induces 'wondering'" (29). Bracciano himself is provoked into a rather unsavoury form of intellectual "wonder" by the events, seeking to know in more precise detail the ingenious means of their slaughter. Indeed, the dumb shows' rhetorical inflection complicates action and interpretation by suggesting that visual stage action is a form of second-hand testimony. Lorna Hutson's study of Shakespearean character argues that "circumstance" provides probable motives and feelings for characters (and that it is therefore central to sixteenth- and seventeenth-century England's dramaturgy). She notes that treatises and manuals of the period profess how "circumstances give credibility to a narrative, and, on the other hand" teach one "how to use them to inquire into that narrative for inconsistencies and improbabilities" (79). Such possibilities are both piqued and frustrated in The White Devil, where the language of forensic rhetoric indicates that the Conjuror's less than charming spectacles are attempts to construct an event and not unmediated access to it. Such difficulties prompt questions about evidence, moral judgement, visual certainty, and sceptical philosophy that resonate throughout the succeeding scenes. 
Verbal expression and visual action are traditionally connected in classical oratory, which has a crucial physical element of action; Jacobean rhetoric, however, begins to develop a closer connection between rhetorical ornament and visual display (see Keir Elam's notion of "expressive" rhetoric). Thomas Wright's influential treatise on the passions considers, in its 1604 edition, dumb shows in particular to be closely related to rhetorical matters. He links oratory and action by noting that the "internall conceits and affections of our minds, are not only expressed with words, but also declared with actions" (I6v). Wright also continually frames rhetorical persuasion in physical terms, adding a visual aspect to speech itself (beyond the traditional place of "action" in oratory).

Webster also equates language with visual representation. When Bracciano desires further knowledge of "each circumstance," he is told "O 'twas most apparent [. . .] your eye saw the rest, and can inform you / The engine of it all" (2.2.44-46). The Conjuror transforms the witnessed visual display into form of speech: why do you need a verbal narrative of what, who, when, and how-you just saw it right here! The dumb shows are, paradoxically, rhetorical constructions in themselves, and as part of an art of persuasion they are already at one remove from truth and certainty. The multiple meanings of "engine" are brought to the fore, and the term can be read to connote the "vaulting-horse [. . .] brought into the room," Flamineo himself as the murderer, or the whole device of the dumb show. The "engine" here also suggests verbal-visual ingenuity, and the rhetorical associations of the term are suggested by the fact that the murder is a staged echo of an "emblem" (that verbal-visual construction) thrown in at Camillo's window in an earlier scene (2.1.319).

The Conjuror's conclusion that a verbal description of the "engine" is essentially the same as what has just been seen calls to mind the rhetorical tradition of ekphrasis. Ekphrasis can be strictly defined, in late-twentieth-century terms, as "the verbal representation of graphic representation" (Heffernan 299), though Joel Altman has noted its "wider purview" in early modern England, where it encompassed and was sometimes confused with an array of rhetorical categories (274). As a part of the paragone tradition that often sees visual and verbal modes in competition, ekphrasis closely connects and even threatens to unite picture and poetry. While the word only appears in English as a critical term in the eighteenth century, critics including Jean Hagstrum, James A. W. Heffernan, and recently Acheson have 
acknowledged its continuing presence throughout verbal-visual exchanges in the sixteenth and seventeenth centuries. Heffernan acknowledges its potential to offer "a radical critique of representation," not least in its use of "one medium of representation to represent another" (304, 300). The device therefore mirrors the dumb shows in Webster's The White Devil, which themselves collapse distinctions between visual and rhetorical representation by referring to the performances as "circumstances." They represent formal rhetorical persuasion as a material performance — a reverse ekphrasis_-and present the dumb show as a radical representative technique that equates speech and spectacle, a dramatic device that demands a reevaluation of verbal and visual distinctions. Interrogating modes of representation in this way prevents the possibility of straightforward moral judgements; rather, the play insists on a complex process of legal, rhetorical, and ethical enquiry into characters' conduct and guilt.

Webster continues to merge rhetorical devices with visual and material representation in the play's staging of colour. Chiaroscuro is one aspect of the play's chromatic scale that reflects both verbal and dramaturgical techniques, foreshadowing the uses of light that characterise Webster's The Duchess of Malfi and that mark the repertories of candlelit indoor theatres. Indeed, lighting has been of significant focus in Jacobean plays in the Sam Wanamaker Playhouse at Shakespeare's Globe, an "archetype" of a Jacobean indoor playhouse. The range of plays, particularly tragedies, at the SWP shows how handheld candles focus attention on faces and expressions (significant in moments of blushing or cosmetic significance). Bridget Escolme notes how stage play between darkness and lightness also indicates "the shifting boundaries of early modern ideologies of looking, seeing, and watching"—and relatedly, I suggest, speaking_-"and invites us to switch bewilderingly from moral to perverse perspectives" (213). The interactions between moral, visual, and verbal experiences are at the fore in moments of chiaroscuro, as in the SWP's Malfi (dir. Dominic Dromgoole, 2014), where moves from blackness to subtle light revealed the horror of Antonio's dead hand and the tableau of the Duchess's murdered children. A similar effect was in play (with less subtlety, though arguably to more effect) in 'Tis Pity She's a Whore (dir. 
Michael Longhurst, 2014), where the murder of Bergetto was made particularly shocking by playing on the language of light in the scene and plunging the stage (and audience) into pitch blackness and then back to candlelight to reveal a blood-soaked stage.

Chiaroscuro is already, though, a significant feature of the outdoor-performed The White Devil. The play repeatedly riffs on the binary opposition of black and white, just as it does with other "painted" images_from the misogynistic character sketch of a "whore" to references to cosmetics:

I shall be plainer with you, and paint out your follies in more natural red and white than that upon your cheek. (3.2.50-52)

Such references open up another crossover between material theatrical representation and verbal imagery in referencing a male player's constructed appearance (see, separately, Farah Karim Cooper and Andrea Stevens for discussion of the material and poetic meanings of cosmetics on the stage). Colour imagery is in itself tied up with rhetorical ornamentation; by the late Elizabethan period, "the figures or tropes of rhetoric . . . themselves came to be known as the 'colours of rhetoric'” (Mukherji 140). Monticelso's declaration during the arraignment scene (where Vittoria is on trial for murder and adultery) that he will "paint out" Vittoria's follies indicates an explicit use of rhetorical tropes. Though he disingenuously suggests his language is "plainer," Monticelso engages in precisely the type of "painting" he ostensibly condemns (most recently discussed by Derek Dunne); he also makes a claim for speech's participation in the material and the theatrical world, presenting his words as "more natural" than the physical presence of the actor's face. His oratory throughout the scene becomes materially equivalent if not superior to the physical planes of performance, from cosmetics to spectacular dumb shows.

Webster's black-and-white images are more concretely mirrored in the play's stagecraft. The moral implications of blackness or darkness in characters' speech are accompanied by implied or actual staged darkness, signified by the presence of torches on 
stage and by explicit references to dimness: "Come sister, darkness hides your blush" (1.2.180). Marion Lomax notes how

actual or implied darkness is an important feature of both The White Devil and The Duchess of Malfi. [R. B.] Graves draws attention to the fact that Webster was the only dramatist of the period to stage the removal of lights for scenes involving illicit love. As a rhetorical figure, the idea was well-known, but as a dramatic action, it was previously untried. (147)

The play's chiaroscuro doubles visual and verbal figures, transforming the rhetorical device of chiaroscuro into a physical stage effect-a doubling that runs throughout The White Devil and indeed throughout The Duchess of Malfi.

The play's doubling riffs on this distinction between darkness and lightness; Zanche the "moor," mirrors Vittoria in her language and in her "painting." Zanche is continually associated with the language of blackness-particularly in the closing scenes. Her appearance and her hand in the "black deed" (5.3.248) of murder draw on the actor's cosmetics. Indeed, Zanche betrays Vittoria to a disguised Francisco, who appears as a fellow moor, Mulinassar. Meeting the "painted" Francisco, Zanche celebrates her skin colour: "I ne'er loved my complexion till now, / Cause I may boldly say without a blush / I love you" (5.1.203-5). The words align her closely with Vittoria, who earlier speaks of the stage darkness that hides her own blush; for Zanche, it is also theatrical mechanics-the actor's stage paint-that obscure her shame. Both characters play on the interrelationship between speech and theatrical spectacle to suggest a complicated relationship between desire, "saying," and displaying. ${ }^{3}$

Crucially, in the murder scene, a similar doubling of darkness occurs, with Bracciano entering at "dead midnight" and watching his wife "feed her eyes and lips / On the dead shadow" (2.27-28). The stage directions imply that hand-held "lights" illuminate and literally shadow the scene. Indeed, one of the most spectacular elements of the murders is the perfume-fire that burns before the picture and is put out by the Doctor and Christophero before Isabella enters: 
$\ldots$ and then burn perfumes afore the picture and wash the lips of the picture; that done, quenching the fire, and putting off their spectacles, they depart laughing. (2.2.23.3-6) $)^{4}$

At the outdoor Red Bull, burning perfumes signal a contrast between lightness and darkness and work as a stage effect that doubles the language's preoccupations with light and dark. While subtle candlelight would convey the effect well, it is also possible that more elaborate inventions could conjure for an audience the ritual burning of poisoned perfumes; Thomas Hill's 1586 translation of artifice for "matters of pleasure" suggests a range of "effects" created by gunpowder or tallow, including playing with coloured lighting effects (B4v), and John Bate's 1634 treatise points to various pyrotechnic "inventions." Red Bull audiences familiar with theatrical "squibs" (Heywood's earlier Age plays are packed with them) could likewise feed their own eyes and lips as they saw, heard, and smelled in spectacle the language of shadows and fumes. Even in an outdoor playhouse, audiences would be sensitive to lighting conditions (see Graves 532); Webster himself notes that the play was "acted, in so dull a time of winter, presented in so open and black a theatre" ("To The Reader" 5, The White Devil), suggesting, as all British residents know, that afternoon gloom can easily encompass and darken an outside venue, not least one surrounded by tall brick buildings and shrouded in tallow smoke. Webster's complaint suggests light sources are visible and effective dramaturgy in an outdoor theatre's "blackness."

The murder of Isabella is, it is implied by the stage directions, featured in a discovery space or recess, adding to the scene's darkness. It is very difficult to be certain of exactly how and when a discovery space at the Red Bull would be used (Reynolds 158). Such a view has been reinforced more recently by Tim Fitzpatrick and Eva Griffith, though the play nonetheless suggests a number of spaces that are either shrouded by or imply darkness and match spectacle and language: terms like "blackness" and "midnight" are invoked when action occurs in or around these spaces in Webster's play. Indeed, Richard Madelaine identifies a circle of sex and death in early modern drama's recessed spaces, one that forms a "Renaissance poetics of punishment" (160) that "recognized the value of executing 
malefactors near the site of their crimes"; that notion has its rhetorical equivalent in The White Devil, where symbolic color language is physically manifested (as it has been in recent productions at SWP) and rhetorical techniques find their way into the props, technologies, and spaces of the playhouse.

Bracciano's extended death recognizes that his "speeches are several kinds of distractions and in the action should appear so" (5.3.82.1-2; a marginal note in the first quarto), acknowledging the importance of matching action to matter in delivering orations, as articulated above by Wright: "The internall conceits and affections of our minds, are not only expressed with words, but also declared with actions" (I6v). Yet speech throughout the play is linked with action in its broadest sense-not least in the suggestion that the dumb shows might be considered, as circumstances, a very form of "speech."

The White Devils stagecraft aligns with rhetorical features to offer a philosophically complex spectacle—one that opens up a range of legal, philosophical, and ethical questions. Crucially, Webster's alignment of speech and spectacle draws attention to the artificiality not only of what is said in the play but also what is seen. Both are contrivances that manipulate "matter": inventions or engines of rhetorical and physical construction. Though I have concentrated here on more abstract aspects and historical understandings of rhetoric, the connection between speech and spectacle allows for a closer reading of Webster's idiosyncratic rhetorical style that places it within the materials of the playhouse. There is also room for further exploration of the way in which the desired means (from amplifying to sounding "strange") and effects (from persuading to alluring) of rhetoric are closely echoed by comments on, responses to, and descriptions of stage spectacle. As such, the small connections between rhetoric and action teased out here have wider significance in questions about genre, artistic aims, and aesthetic categories in the period. ${ }^{5}$

The conjunction of rhetorical devices and stage devices also appears across other contemporary plays, from numerous ghosts and apparitions through the idiosyncratic verbal style and visual spectacle of Shakespeare's later plays to Middleton's elaborate emblematic 
masques. Indeed, while emblems, impresa, and "engines" of similar kinds have long been recognized as important iconographic structures in early modern stagecraft, ${ }^{6}$ their rhetorical features can be read alongside current scholarship that focuses on the materials of the playhouse. The complex interrelationship between verbal and physical representation does not ignore John Dixon Hunt's concerns about narrowly “iconic" emblematic readings (156). Rather, it attends to material performance at the same time as studying the text, heeding Jenny Sager's recent call for a move away from "a purely text-based interpretation of drama and to emphasise the powerful visual dimension of the early modern stage" (3). It also falls into line with growing interest in notions of metatheatrical "construction" on the stage.

The minutiae of verbal style—down to its formal features and ornaments—have a reciprocal relationship with visual representation on stage. While such a claim is not particularly provocative, it serves as a gloss on recent readings by suggesting that the combination of two often separate critical approaches can bear fruitful discussions of early modern stage spectacle. Steve Urkowitz's intervention in ongoing debates about the relationship between performance and the early printed playtext adds to our awareness that printed plays are complexly related to their performed counterparts and that the length of a published text does not necessarily mean a more "literary" version. Urkowitz believes that early modern plays

challenged rather than pandered to their audiences, their censors, and themselves as they wrote, revised and played more and more daring, more and more demanding, and, yes, more and more lengthy scripts that may perhaps have been copied and printed for private reading but primarily were played at full length (or approximately full length) for public, private, and courtly performances in London and on tour for crowds of attentive listeners and observers. (257)

Our close reading of the text need not always be seen as a radically different activity from wider attention to early performances and the more material preoccupations of theatre history. The complex rhetorical structures, elements, ornamentation, and devices that characterise so many plays of the early seventeenth century are not only perceptible on the 
page but are teasingly in play during performance. Like Wright's conception of rhetorical style in The Passions of the Mind, plays were thought to "imprint" themselves upon spectators.

Critics should attend to such impressions by seeing speech as an integral part of spectacle, and vice versa. As different descriptions of playgoing from the period suggest, ${ }^{7}$ perhaps to see and hear a play are two sides of the same coin. 


\section{Notes}

${ }^{1}$ Hamlet makes a similar joke when responding to Polonius, who replies: "I mean the matter that you read" (2.2.192); interestingly, the Folio prints the response as "I meane the matter that you meane" (Oo3r), further complicating the meaning of the term.

${ }^{2}$ Jan-Melissa Schramm notes its judicial function as "evidence of a subsidiary fact from which the existence of the primary fact may be inferred" and explains that "if testimony as to the main fact can be criticised as incomplete or misleading, then so can the testimonial presentation of circumstantial evidence" $(19,20)$.

${ }^{3}$ For a recent discussion of stage blushing and its relationship to "truth," see Derek Dunne.

${ }^{4}$ Philip Butterworth's study of fireworks in theatrical display illuminates the various ways in which such action might have been performed.

${ }^{5}$ See Mark Robson for a provocative discussion of rhetoric and early modern "aesthetics" that explores the anachronism of the latter term.

${ }^{6}$ See Helen Cooper; Peter M. Daly; Huston Diehl; Ruth Lunney.

7 Gabriel Egan's thorough survey shows that "seeing" was much more common than

"hearing," though both terms were used when describing attendance at a stage play.

\section{Works Cited.}

Acheson, Katherine. Visual Rhetoric and Early Modern English Literature. Farnham: Ashgate, 2013. Print.

Altman, Joel. The Tudor Play of Mind: Rhetorical Inquiry and the

Development of Elizabethan Drama. London: U California P, 1978.

Print.

Bath, Michael. Speaking Pictures: English Emblem Books and Renaissance

Culture. Harlow: Longman, 1994. Print.

Berry, Ralph. The Art of John Webster. Oxford: Clarendon, 1972. Print.

Bourne, William. Inuentions or deuises. . London, 1590. Early English

Books Online. Web. 26 Feb. 2014.

Butterworth, Philip. Theatre of Fire: Special Effects in Early English and

Scottish Theatre. London: Society for Theatre Research, 1998. Print.

Carey, Katherine M. "The Aesthetics of Immediacy and Hypermediation: The

Dumb Shows in Webster's The White Devil." New Theatre Quarterly 23

(2007): 73-80. Print.

Coleman, David. John Webster: Renaissance Dramatist. Edinburgh:

Edinburgh UP, 2010. Print. 
Crooke, Helkiah. Mikrokosmographia. London, 1615. Print.

The Duchess of Malfi. By John Webster. Dir. Dominic Dromgoole. Perf.

Gemma Arterton, Alex Waldmann, Sean Gilder, David Dawson, James

Garnon. Shakespeare's Globe. Sam Wanamaker Playhouse,

Shakespeare's Globe, London. 9 Jan.-16 Feb. 2014. Performance.

Dunne, Derek. "Blushing on Cue: The Forensics of the Blush in Early Modern

Drama." Shakespeare Bulletin 34.2 (2016): 233-248. Project Muse.

Web. 24 June 2016.

Escolme, Bridget. "The Duchess of Malfi, The Knight of the Burning Pestle,

and The Malcontent: Shakespeare's Globe, January-April 2014."

Shakespeare Quarterly 65.2 (2014): 209-218. Project Muse. Web. 24

June 2016.

Egan, Gabriel. "Hearing or Seeing a Play?: Evidence of Early Modern

Theatrical Terminology." Ben Jonson Journal 8 (2001): 327-47. De

Montfort University. Web. 2 Feb. 2016.

Elam, Keir. "Early Modern Syntax and Late Shakespearean Rhetoric." Early

Modern English: Trends, Forms, Texts. Ed. C Nocera Avila, N.

Pantaleo, and D. Pizzini. Fasano: Schena Editore, 1992. 63-80. Print.

Estienne, Henri. The art of making devises. Trans. Thomas Blount. London, 1646. Print.

Evelyn Papers Vol. CCCCLXV. c.1687. MS. Add. 78632. British Library, London.

Fitzpatrick, Tim. Playwright, Space, and Place in Early Modern Performance.

Farnham: Ashgate, 2011. Print.

Graves, R. B. "Lighting." The Oxford Handbook of Early Modern Theatre.

Ed. Richard Dutton. Oxford: Oxford UP, 2009. 528-542. Print.

Griffith, Eva. A Jacobean Company and its Playhouse: The Queen's Servants at the Red Bull Theatre (c. 1605-1619). Cambridge: Cambridge UP, 2013. Print.

Gurr, Andrew and Farah Karim-Coooper, ed.. Moving Shakespeare Indoors:

Performance and Repertoire in the Jacobean Playhouse. Cambridge:

Cambridge UP, 2014. Print. 
Hagstrum, Jean H. The Sister Arts: The Tradition of Literary Pictorialism and English Poetry from Dryden to Gray. Chicago: U of Chicago P, 1958. Print.

Harris, Jonathan Gil. Untimely Matter in the Time of Shakespeare.

Philadelphia: $U$ of Philadelphia P, 2008. Print.

Harris, Jonathan Gil and Natasha Korda, ed. Staged Properties in Early Modern English Drama. Cambridge: Cambridge UP, 2002. Print. Heffernan, James A. W. "Ekphrasis and Representation." New Literary History 22.2 (1991): 297-316. JSTOR. Web. 14 Mar. 2015.

Hill, Thomas. A Briefe and pleasaunt treatise, intituled, Naturall and artificiall conclusions. ... London, 1581. Early English Books Online. Web. 27 Feb. 2014.

Hunt, John Dixon. "Pictura, Scriptura, and Theatrum: Shakespeare and the Emblem." Poetics Today 10.1 (1989): 155-171. JSTOR. Web. 2 Feb. 2016

Hutson, Lorna. "Law, Probability and Character in Shakespeare." Fictions of Knowledge: Fact, Evidence, Doubt. Ed. Yoka Batsaki, Subha Mukherji, and Jan-Melissa Schramm. Basingstoke: Palgrave Macmillan, 2012. Print.

Jones, Gwilym. Shakespeare’s Storms. Manchester: Manchester UP, 2015. Print.

Jonson, Ben. "An Expostulation on Inigo Jones." The Works of Ben Jonson, vol. 8. Ed. W. Gifford. London: W. Bulmer and Co., 1816. 116-119. Print.

Karim-Cooper, Farah and Tiffany Stern. "Introduction." Shakespeare's Theatres and the Effects of Performance. Ed. Farah Karim-Cooper and Tiffany Stern. London: Arden Bloomsbury, 2013. 1-8. Print.

--- ed. Shakespeare's Theatres and the Effects of Performance. London: Arden Bloomsbury, 2013. Print.

Lomax, Marion. Stage Images and Traditions: Shakespeare to Ford. Cambridge: Cambridge UP, 1987. Print.

Mack, Peter. Elizabethan Rhetoric: Theory and Practice. Cambridge: Cambridge UP, 2002. Print. 
Madelaine, Richard. “'The dark and vicious place': The Location of Sexual Transgression and its Punishment on the Early Modern English Stage." Parergon 22.1 (2005): 159-183. Project Muse. Web. 16 Sep. 2015.

Meek, Richard. Narrating the Visual in Shakespeare. Farnham: Ashgate, 2009. Print.

Menzer, Paul. "In the Event of Fire." Moving Shakespeare Indoors:

Performance and Repertoire in the Jacobean Playhouse. Ed. Andrew

Gurr and Farah Karim-Cooper. Cambridge: Cambridge UP, 2014. 168-

183. Print.

Mignault, Claude. "De Emblematis." Emblemata. Andrea Alciato. Lyons,

1614. A7r-A8r. The Internet Archive. Web. 13 May 2013.

Mukherji, Subha. Law and Representation in Early Modern Drama.

Cambridge: Cambridge UP, 2006. Print.

Peacham, Henry. The Garden of Eloquence. London, 1593. Early English

Books Online. Web. 14 Sep. 2015.

Pearson, Jacqueline. Tragedy and Tragicomedy in the Plays of John

Webster. Manchester: Manchester UP, 1980. Print.

la Perrière, Guillaume. The theater of fine deuices... London, 1614. Early

English Books Online. Web. 13 Mar. 2013.

Porter, Chloe. Making and Unmaking in Early Modern English Drama:

Spectators, Aesthetics, and Incompletion. Manchester: Manchester UP, 2013. Print.

Pye, Christopher. The Storm at Sea: Political Aesthetics in the Time of Shakespeare. New York: Fordham UP, 2015. Print.

Reynolds, George F. The Staging of Elizabethan Plays at the Red Bull Theatre, 1605-1626. 1940. New York: Kraus, 1966. Print.

Robson, Mark. The Sense of Early Modern Writing. Manchester: Manchester UP, 2006. Print.

Rochester, Joanne. Staging Spectatorship in the Plays of Philip Massinger.

Farnham: Ashgate, 2010. Print. 
Sager, Jenny. The Aesthetics of Spectacle in Early Modern Drama and Modern Cinema: Robert Greene's Theatre of Attractions. London: Palgrave, 2013. Print.

Schramm, Jan-Melissa. Testimony and Advocacy in Victorian Law, Literature, and Theology. Cambridge: Cambridge UP, 2000. Print.

Shakespeare, William. Hamlet. The Norton Shakespeare. 2016. Ed.

Stephen Greenblatt et al. 3rd ed. London: Norton, 2016. 1764-1856.

Print.

Skinner, Quentin. Reason and Rhetoric in the Philosophy of Hobbes. Cambridge: Cambridge UP, 1996. Print.

Sofer, Andrew. The Stage Life of Props. Ann Arbor: U of Michigan P, 2003. Print.

Stevens, Andrea. Inventions of the Skin: The Painted Body in Early English Drama, 1400-1642. Edinburgh: Edinburgh UP, 2013. Print.

'Tis Pity She's a Whore. By John Ford. Dir. Michael Longhurst. Perf. Max Bennett, Fiona Button, James Garnon. Shakespeare's Globe. Sam Wanamaker Playhouse, Shakespeare's Globe, London. 23 Oct.-7 Dec. 2014. Performance.

Turner, Henry S. The English Renaissance Stage: Geometry, Poetics, and the Practical Spatial Arts, 1580-1630. Oxford: Oxford UP, 2006. Print.

Tymme, Thomas. A dialogue philosophicall. London, 1612. Early English Books Online. Web. 15 Sep. 2015.

Urkowitz, Steve. "Did Shakespeare's Company Cut Long Plays Down to Two Hours Playing Time?" Shakespeare Bulletin 30.3 (2012): 239-62. Project Muse. Web. 2 Feb. 2016.

Webster, John. The White Devil. Ed. Christina Luckyj. London: Methuen, 2008. Print.

Wilson, Thomas. The arte of rhetorique for the vse of all suche as are studious of eloquence, sette forth in English. London, 1553. Early English Books Online. Web. 30 Dec. 2013.

Woods, Penelope. "The Audience of the Indoor Theatre." Moving Shakespeare Indoors: Performance and Repertoire in the Jacobean 
Playhouse. Ed. Andrew Gurr and Farah Karim-Cooper. Cambridge: Cambridge UP, 2014. 152-67. Print.

Wright, Thomas. The passions of the minde in general. London, 1604. Early English Books Online. Web. 14 Sep. 2015.

\section{Bibliography.}

Bath, Michael. Speaking Pictures: English Emblem Books and Renaissance Culture. Harlow: Longman, 1994. Print.

Daly, Peter M. “The Case for the 1593 Edition of Thomas Combes's Theater of Fine Devices." Journal of the Warburg and Courtauld Institutes 49 (1986): 255-257. JSTOR. Web. 15 Sep. 2015.

---. Literature in Light of the Emblem. London: $U$ of Toronto P, 1979. Print.

Daly, Peter M. and John Manning, ed. Aspects of Renaissance and Baroque Symbol Theory 1500-1700. New York: AMS, 1999. Print.

Freeman, Rosemary. English Emblem Books. London: Chatto \& Windus, 1948. Print.

Hutson, Lorna. The Invention of Suspicion: Law and Mimesis in Shakespeare and Renaissance Drama. Oxford: Oxford UP, 2007. Print.

Ichikawa, Mariko. "Continuities and Innovations in Staging." Moving Shakespeare Indoors: Performance and Repertoire in the Jacobean Playhouse. Ed. Andrew Gurr and Farah Karim-Cooper. Cambridge: Cambridge UP, 2014. 79-94. Print.

Kermode, Frank. Shakespeare's Language. 2000. London: Penguin, 2001. Print.

Lopez, Jeremy. "Dumb Show." Early Modern Theatricality. Ed. Henry S. Turner. Oxford: Oxford UP, 2013. 291-305. Print.

McDonald, Russ. Shakespeare's Late Style. Cambridge: Cambridge UP, 2006. Print.

Mehl, Dieter. The Elizabethan Dumb Show: The History of a Dramatic Convention. London: Methuen, 1964. Print. 